\title{
Two New Species of Lactobacillus Isolated from the Bovine Rumen, Lactobacillus ruminis sp.nov. and Lactobacillus vitulinus sp.nov.
}

\author{
By M. ELISABETH SHARPE, M. J. LATHAM, ELLEN I. GARVIE \\ National Institute for Research in Dairying, Reading, Berkshire \\ AND J. ZIRNGIBL AND O. KANDLER \\ Botanical Institute, University, Munich, Germany.
}

(Received 26 October 1972; revised 6 February 1973)

SUMMARY

Two new anaerobic species of Lactobacillus from the bovine rumen are described. They belong to the subgenus Thermobacterium and contain meso diaminopimelic acid in the wall peptidoglycan. The species differ from each other in being motile and non-motile, in the type of lactic acid produced and in $\%$ base composition of their DNA. They have been named Lactobacillus ruminis and L. vitulinus.

\section{INTRODUCTION}

During an investigation of the effect of high-carbohydrate diets on the microflora of the bovine rumen (Latham, Sharpe \& Sutton, 197I; J. D. Sutton, unpublished), motile, anaerobic strains of Gram-positive rods were occasionally isolated. When present these organisms occurred in high dilutions of rumen contents and constituted part of the majority flora of the rumen at the time of sampling. As motile lactobacilli have been described previously (Harrison \& Hansen, 1950; Mann \& Oxford, 1954; Thornley \& Sharpe, I959: Langston \& Bouma, I960; Gemmell \& Hodgkiss, 1964; Reuter, 1970) the rumen strains were further investigated to determine their relationships to some of these and to other known species of Lactobacillus. Also, two non-motile strains of anaerobic Gram-positive rods, isolated as part of the majority flora from the rumen of a 6-month-old steer on a hay and concentrates diet, were examined and compared with two strains of anaerobic lactobacilli previously isolated and described by Bryant, Small, Bouma \& Robinson (1958).

\section{METHODS}

Bacteria. The six rumen strains were isolated from samples of rumen contents of animals on the diets shown in Table I. Cows A, B and C were non-lactating, rumen-fistulated animals: animal $\mathrm{D}$ was a 6-month-old steer and the rumen sample was obtained by stomach tube. Strains were isolated using the anaerobic techniques of Hungate (1950) on Medium 10 of Caldwell \& Bryant (I966), modified as described by Latham \& Sharpe (1971). The sources of laboratory and collection strains are described in Table $\mathrm{I}$.

For all cultural work the eight rumen isolates were grown in a McIntosh and Fildes anaerobic jar under an atmosphere of $90 \% \mathrm{H}_{2}+10 \% \mathrm{CO}_{2}$ at $30{ }^{\circ} \mathrm{C}$, and the four other strains were grown in air at $37^{\circ} \mathrm{C}$.

Detection of motility. Motility was tested after $\mathrm{i} 8 \mathrm{~h}$ of incubation in the fluid of synerisis of Medium 10 agar slopes, and after $6 \mathrm{~h}$ of incubation in sloppy Medium 10 agar $(0.25 \% \mathrm{w} / \mathrm{v}$, 
Table I. Strains of Lactobacillus examined

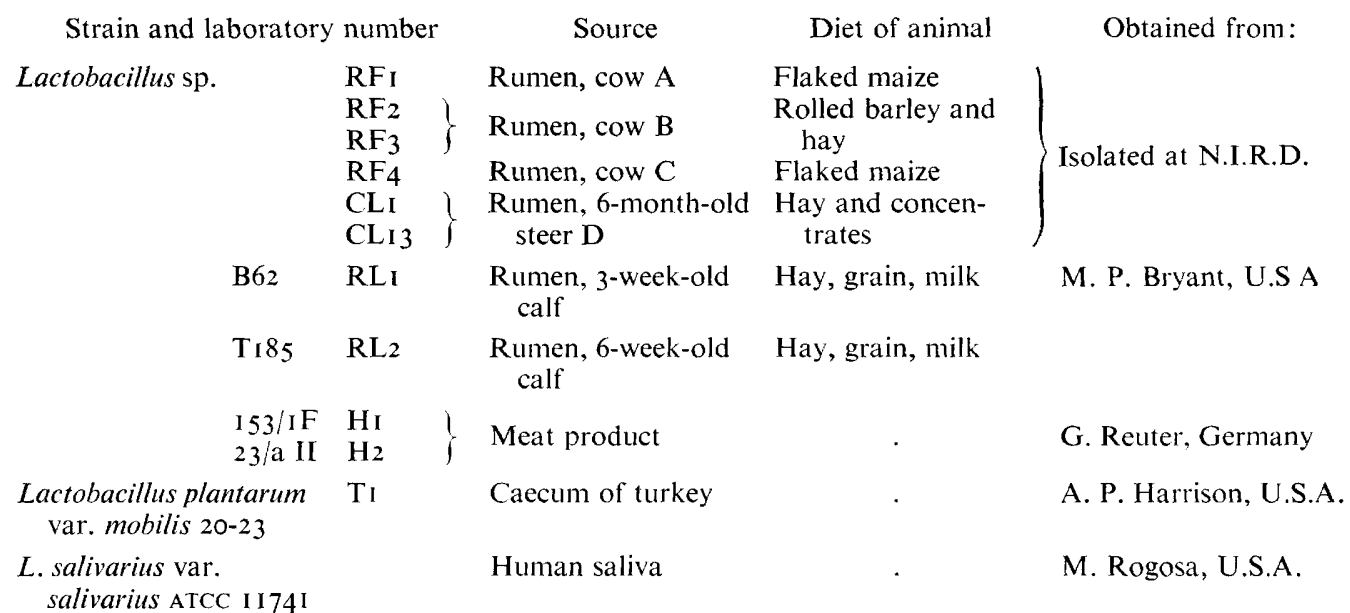

agar), stabs and MRS broth (de Man, Rogosa \& Sharpe, 1960) modified to contain only $0.05 \%(w / v)$ glucose.

Flagella staining and electron microscopy. Bacteria were stained using the method of Rhodes (I958) and observed with the light microscope. For electron microscopy, droplets of bacterial suspension were placed on formvar-coated grids and shadowed with gold palladium (40/60 w/w) at an angle of $22^{\circ}$. The grids were examined in a Siemens Elstrop I electron microscope.

Physiological tests for identification. The methods of Sharpe, Fryer \& Smith (I966) and Rogosa (1970) were used, $0.02 \%$ (w/v) cysteine $\mathrm{HCl}$ being added to all media.

Growth in selective lactobacillus medium. Some strains were inoculated into the acetate medium of Rogosa, Mitchell \& Wiseman (I95I) which is selective for lactobacilli, pediococci and some leuconostocs.

Fermentation products. To determine free fatty acids, strains were grown for $48 \mathrm{~h}$ in MRS broth, with acetate omitted and $0.02 \%(\mathrm{w} / \mathrm{v})$ cysteine $\mathrm{HCl}$ added. After centrifuging, a portion $(5 \mathrm{ml})$ of the supernatant was analysed on a silicic acid column, by the method of Harper, Schwartz \& El-Hagarawy (I956). To determine lactic acids the strains were grown for $48 \mathrm{~h}$ in MRS broth, with meat extract omitted and $0.02 \%(\mathrm{w} / \mathrm{v})$ cysteine $\mathrm{HCl}$ added, and the supernatants tested. Or washed cell suspensions were allowed to ferment glucose in phosphate buffer at pH 5.6 (Abo Elnaga \& Kandler, 1965) and the supernatants tested. The method of Bergmeyer (1962) with L-lactate (EC. I.I.I.27) and D-lactate (EC. I.I.I.28) dehydrogenases (Boehringer, Mannheim) was used to determine $\mathrm{L}(+)$ - and $\mathrm{D}(-)$-lactic acids.

Determination of lactate dehydrogenases in strain RFI. The lactate dehydrogenase-linked oxidation of NADH and reduction of NAD, and electrophoresis of the enzymes were studied by the methods of Garvie (1969), except that electrophoresis was carried out in cylindrical gels and sucrose (final concentration 5 to $10 \%, \mathrm{w} / \mathrm{v}$ ) added to the crude enzyme preparation before layering it on to the gel surface.

To convert pyruvate to lactate, one drop of concentrated, crude, bacterial extract was added to a reaction mixture consisting of $\mathrm{I} .0 \mathrm{ml}$ tris $(0.2 \mathrm{M})+$ maleate buffer at the required $\mathrm{pH}$ values of $6 \cdot 3,7 \cdot 0,7 \cdot 5$ or $8 \cdot 3, \mathrm{I} \cdot \mathrm{I} \mathrm{mg}$ sodium pyruvate, $7 \cdot 0 \mathrm{mg} \mathrm{NADH}$ and $\mathrm{I} \cdot 0 \mathrm{ml}$ water. After incubation at $22{ }^{\circ} \mathrm{C}$ for $5 \mathrm{~h}$, preparations were treated with acid-washed charcoal 
(Sutcliffe, Speakman no. 5) to remove NAD and residual NADH, and centrifuged. The supernatants were held at $100{ }^{\circ} \mathrm{C}$ for $5 \mathrm{~min}$ and deep frozen until tested for total and $\mathrm{L}(+)$-lactic acid (Garvie, 1967), D(-)-lactic acid being estimated by difference.

Preparation and analysis of walls. Bacteria were disrupted by shaking with glass beads and the crude wall preparation treated by tryptic digestion as described by Schleifer \& Kandler (1967). The walls were hydrolysed in $4 \mathrm{~N}-\mathrm{HCl}$ for $\mathrm{I} 4 \mathrm{~h}$ at $100{ }^{\circ} \mathrm{C}$ and the qualitative and quantitative amino acid composition of the total hydrolysate determined using an amino acid analyser (Beckman I $20 c$, Beckman Instruments). The amino acid sequence of the peptidoglycan was checked by two-dimensional paper chromatography of partial hydrolysates of the wall (Schleifer \& Kandler, 1967; 1970). The resulting 'finger prints' were compared with those from previously investigated organisms which possessed walls of the same amino acid composition. When the pattern of the oligopeptides was identical it was assumed that the amino acid sequence was also identical.

For the detection of sugar components, walls were hydrolysed in $2 \mathrm{~N}-\mathrm{HCl}$ for $2 \mathrm{~h}$ and the hydrolysate was analysed by two dimensional paper chromatography using the following solvent systems: $n$-butanol + pyridine + water + acetic acid (60:40:30:3); water saturated phenol+ IM-Na $\mathrm{NDDTA}_{2}$ acetic acid (I000:I:10). Chromatograms were sprayed with alkaline silver nitrate (Trevelyan, Procter \& Harrison, I950).

Teichoic acid was extracted from the walls by incubating with $10 \%(\mathrm{w} / \mathrm{v})$ TCA at $4 \mathrm{C}$ for 3 days, centrifuging, adding 2 vol. of ethanol to the supernatant and harvesting the precipitated teichoic acid by centrifugation. After hydrolysis with $2 \mathrm{~N}-\mathrm{HCl}$ for I h at $100{ }^{\circ} \mathrm{C}$ sugar components were determined by chromatography as described above, and phosphate by the method of Fiske \& Subbarow (1925).

Deoxyribonucleic acid base composition. The method of Marmur \& Doty (I962) was used.

Serological tests. The general methods for agglutination tests were those described by Sharpe, Latham \& Reiter (I969). An antiserum was prepared against strain RFI, which was grown for $18 \mathrm{~h}$ in MRS broth $+0.02 \%(\mathrm{w} / \mathrm{v})$ cysteine $\mathrm{HCl}$ and then suspended in $0.2 \%$ $(\mathrm{v} / \mathrm{v})$ formaldehyde in $\mathrm{O} \cdot \mathrm{I} 5 \mathrm{M}-\mathrm{NaCl}$. Formolized suspensions of organisms for agglutination tests were prepared in the same way, and tests performed using doubling dilutions of antiserum.

\section{RESULTS}

The four strains, RFI to RF4, from cows $\mathrm{A}, \mathrm{B}$ and $\mathrm{C}$ were among those picked from roll tubes at a dilution of $10^{-8} \mathrm{~g}$ rumen contents. With steer $\mathrm{D}$, in which the viable count was only $3.2 \times 10^{8} / \mathrm{g}$, colonies were picked from the $10^{-7}$ dilution, where strains morphologically similar to CLI and CLI 3 comprised $50 \%$ of the majority flora of the rumen contents. Strains RFI-RF4 were Gram-positive, non-sporing, regular rods. Strains CLI and CLI 3 were Gram-positive, club-shaped or irregular rods, morphologically similar to bifidobacteria. As all six strains grew well in boiled MRS broth $+0.02 \%(\mathrm{w} / \mathrm{v})$ cysteine $\mathrm{HCl}$ incubated in a conventional anaerobic jar, the Hungate techniques were unnecessary for cultivation. Strains RLI and RL2 also grew under conventional anaerobic conditions in MRS broth + $0.02 \%(\mathrm{w} / \mathrm{v})$ cysteine $\mathrm{HCl}$. In MRS broth under aerobic conditions strains CLI, CLI3, RLI, RL2 did not grow at all, and RFI to RF4, which on first isolation did not grow in this medium, grew only scantily after laboratory cultivation. Strains HI, H2, TI and ATCC 1174I grew aerobically in MRS broth but were cultured in MRS broth $+0.02 \%(w / v)$ cysteine to conform to the medium used for the other strains.

Motility. Strains RFI to RF4 were originally observed to be motile in the fluid of syneresis of Medium Io agar slopes. These strains exhibited motility more consistently in Medium Io, 


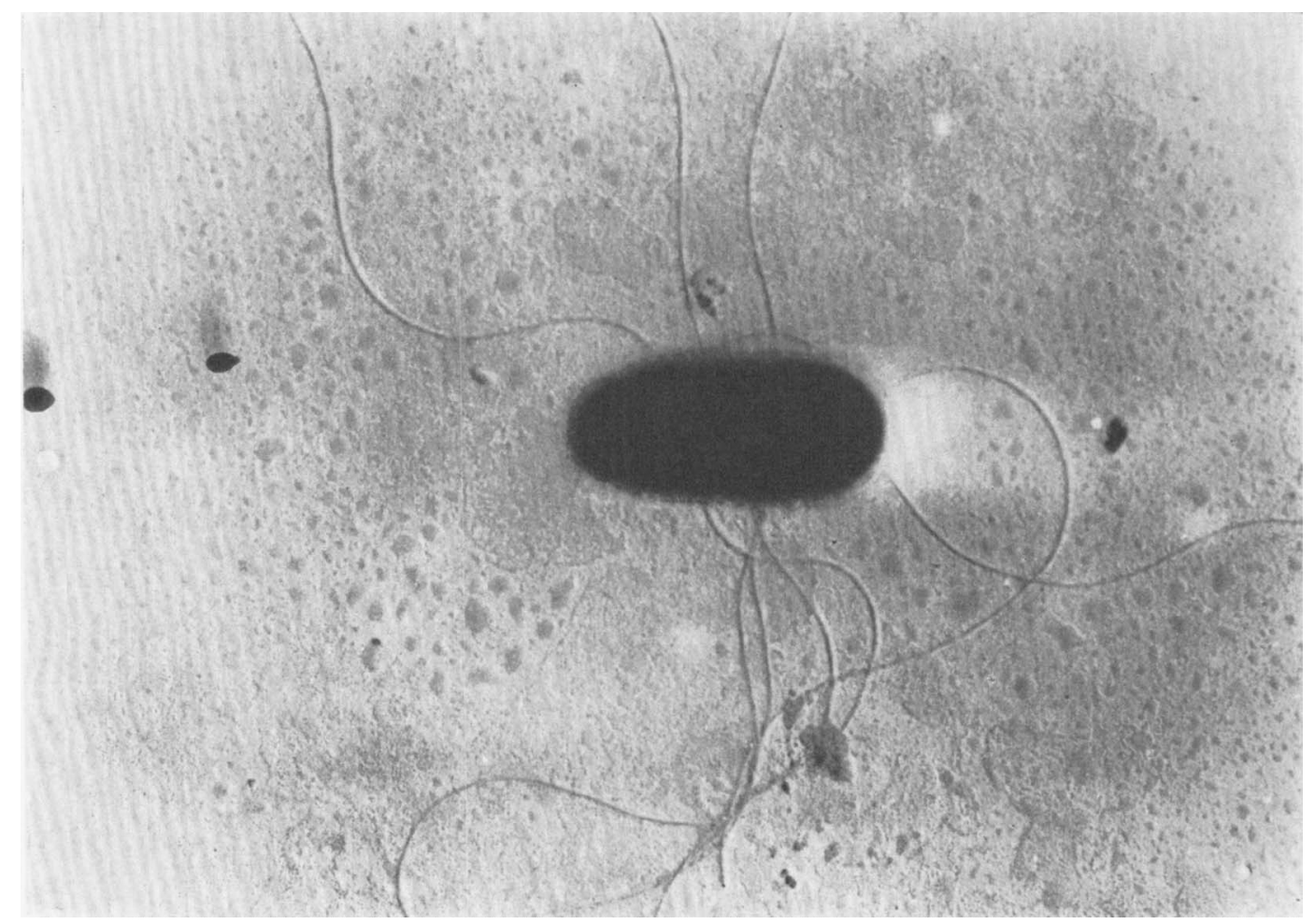

Fig. I. Electron micrograph of Lactobacillus ruminis RFI, showing peritrichous flagella.

but strains HI and TI were more frequently observed to be motile in the MRS broth with low glucose content. Motility was not always easy to demonstrate and was often only sluggish. However, strains CLI, CLI3, RLI, RL2, H2 and ATCC II74I were consistently nonmotile. ATCC II74I was described as motile by Gemmell \& Hodgkiss (1964), and H2 was motile on first isolation, but this characteristic was later lost (Reuter, 1970). This loss may occur on laboratory cultivation, particularly in media containing high carbohydrate levels, customary for lactobacilli, which discourage motility. The motility of the rumen microorganism Butyrivibrio fibrisolvens may be temporarily suppressed if the carbohydrate concentration in the medium exceeds $0.1 \%$ (Bryant \& Small, 1956).

Flagella staining and electron microscopy. Stained preparations of RFI, RF2, RF3 and RF4 showed the presence of peritrichous flagella, and this was confirmed by electron microscopy of strain RFI (Fig. I). Previous workers with motile lactobacilli (Harrison \& Hansen, I950; Gemmell \& Hodgkiss, 1964) also demonstrated peritrichous flagella.

Physiological tests. All strains tested were homofermentative and catalase-negative. By our method of testing RLI did not produce gas from glucose, although Bryant et al (1958) observed slight gas production. As several homofermentative strains of lactobacilli have been observed previously to produce small amounts of gas on occasion this was not regarded as significant. All eight rumen strains had similar fermentation patterns (Table 2) except that strains CLI, CLI3, and RL2 fermented inulin weakly, RL2 fermented sorbitol and RLI fermented trehalose. Strains TI and ATCC I I 74I differed from the rumen strains in that they fermented mannitol and grew well aerobically. They were differentiated from each other, 
Table 2. Physiological characteristics of twelve strains of Lactobacillus

\begin{tabular}{|c|c|c|c|c|c|c|c|c|c|c|c|c|}
\hline & RFI & RF2 & RF3 & $\mathrm{RF} 4$ & CLI & CLI3 & RLI & RL2 & $\mathrm{TI}$ & $\mathrm{HI}$ & 112 & $\begin{array}{l}\text { ATCO } \\
11741\end{array}$ \\
\hline Growth at $15 \mathrm{C}$ & - & - & - & - & - & - & - & - & - & + & + & - \\
\hline $45 \mathrm{C}$ & + & + & + & . & + & + & + & + & + & - & - & + \\
\hline Motility & + & + & + & + & - & - & - & - & + & + & - & - \\
\hline Aerobic growth & - & - & - & - & - & - & Slight & - & + & + & + & + \\
\hline $\mathrm{pH}$ in MRS broth & $4 \cdot 1$ & $3 \cdot 9$ & $4 \cdot 3$ & . & $4 \cdot 5$ & $4 \cdot 4$ & $4 \cdot 2$ & $4 \cdot 3$ & $3 \cdot 8$ & $4 \cdot 2$ & $4 \cdot 0$ & $3 \cdot 7$ \\
\hline Fermentation of: & & & & & & & & & & & & \\
\hline Ribose & - & - & - & . & - & - & - & - & + & + & + & - \\
\hline Rhamnose & - & - & - & . & - & - & - & - & - & - & - & $+w$ \\
\hline Sucrose & + & + & + & + & + & + & + & + & + & + & - & + \\
\hline Trehalose & - & - & - & - & - & - & + & - & - & + & - & + \\
\hline Cellobiose & + & + & + & . & + & + & + & + & + & + & + & - \\
\hline Melibiose & + & + & + & + & + & + & + & + & $\div$ & - & - & + \\
\hline Raffinose & + & + & $\div$ & + & + & + & + & $\div$ & $\div$ & - & - & + \\
\hline Inulin & - & - & - & - & $+w$ & $+w$ & - & $+w$ & - & - & - & - \\
\hline Lactose & + & - & - & -- & + & + & + & + & $\div$ & + & + & + \\
\hline Mannitol & - & - & - & - & - & - & - & - & + & - & - & + \\
\hline Sorbitol & - & - & - & $\cdots$ & - & - & - & + & + & - & - & + \\
\hline Salicin & + & + & + & + & + & + & + & + & $\div$ & + & + & - \\
\hline Aesculin & + & + & + & + & + & + & + & + & + & + & + & - \\
\hline Lactic acid: & & & & & & & & & & & & \\
\hline${ }_{0}^{\circ} \mathrm{D}(-)$ & 5 & 3 & 5 & 5 & 100 & $\begin{array}{r}100 \\
0\end{array}$ & $\begin{array}{r}100 \\
0\end{array}$ & $\begin{array}{r}100 \\
0\end{array}$ & $\begin{array}{r}8 \\
92\end{array}$ & $\begin{array}{l}45 \\
55\end{array}$ & $\begin{array}{l}50 \\
50\end{array}$ & $\begin{array}{r}1 \\
99\end{array}$ \\
\hline o L $(+)$ & 95 & 97 & 95 & 95 & o & O & 0 & & 92 & 55 & 50 & 99 \\
\hline
\end{tabular}

All strains fermented fructose, glucose, galactose, mannose, maltose, amygdalin. None fermented xylose, arabinose, melezitose, glycogen, glycerol, inositol. None produced gas from glucose or from gluconate. None hydrolysed arginine.

+ , Strong fermentation; $+w$, weak fermentation; - , no fermentation; ., no test.

as $\mathrm{T}$ I fermented ribose and cellobiose and hydrolysed aesculin and salicin whilst ATCC I 174 I did not. Strains $\mathrm{HI}$ and $\mathrm{H} 2$ differed from the others in growing at $15{ }^{\circ} \mathrm{C}$, in failing to ferment melibiose and raffinose, and from all but TI in fermenting ribose.

Growth on acetate media. Strains RFI, RF2, RF3, CLI, CLI 3 and TI grew well under anaerobic conditions in the selective, acetate broth medium of Rogosa, Mitchell \& Wiseman (1951).

Fermentation products. No acetic, propionic, butyric or higher volatile fatty acids were detected in the broth supernatants of the strains tested (RFI, RF2, RF3, CLI and CLI3). Lactic acid was produced by all twelve strains. The lactic acid produced by RFI to RF4 was almost entirely $\mathrm{L}(+)$, with only about $5 \% \mathrm{D}(-)$, whilst CLI, CLI3, RLI and RL2 produced only D(-)-lactic acid (Table 2 ). Strains TI and ATCC I I 74I also produced almost entirely $\mathrm{L}(+)$-lactic acid, whilst $\mathrm{HI}$ and $\mathrm{H} 2$ differed from all the others by producing equal amounts of $\mathrm{D}(-)$ and $\mathrm{L}(+)$.

Lactate dehydrogenases of strain RFI. Oxidation of NADH and reduction of NAD, were both followed at $340 \mathrm{~nm}$ and the latter also using nitroblue tetrazolium and phenazine methosulphate as reduction links. The results showed that RFI had two NAD-linked lactate dehydrogenases (EC. I.I.I.27, 28). No NAD non-linked ones (EC. I.I.99.-) were detected. The enzyme forming $\mathrm{L}(+)$-lactic acid had an optimum $\mathrm{pH}$ of about 5.5 and the reaction was almost irreversible, whilst the enzyme forming $\mathrm{D}(-)$-lactic acid had a reaction reversible above $\mathrm{pH} 7 \cdot 0$. On electrophoresis the $\mathrm{D}(-)$-enzyme, which migrated faster than the $\mathrm{L}(+)$-enzyme, moved to a position close to the enzyme of Lactobacillus lactis NCDO 280. The $\mathrm{L}(+)$-enzyme was close to the $\mathrm{L}(+)$-enzyme of $L$. plantarum NCDO 82. Fructose-1,6diphosphate did not influence the activity of either the $(D-)$ - or $L(+)$-enzyme. 


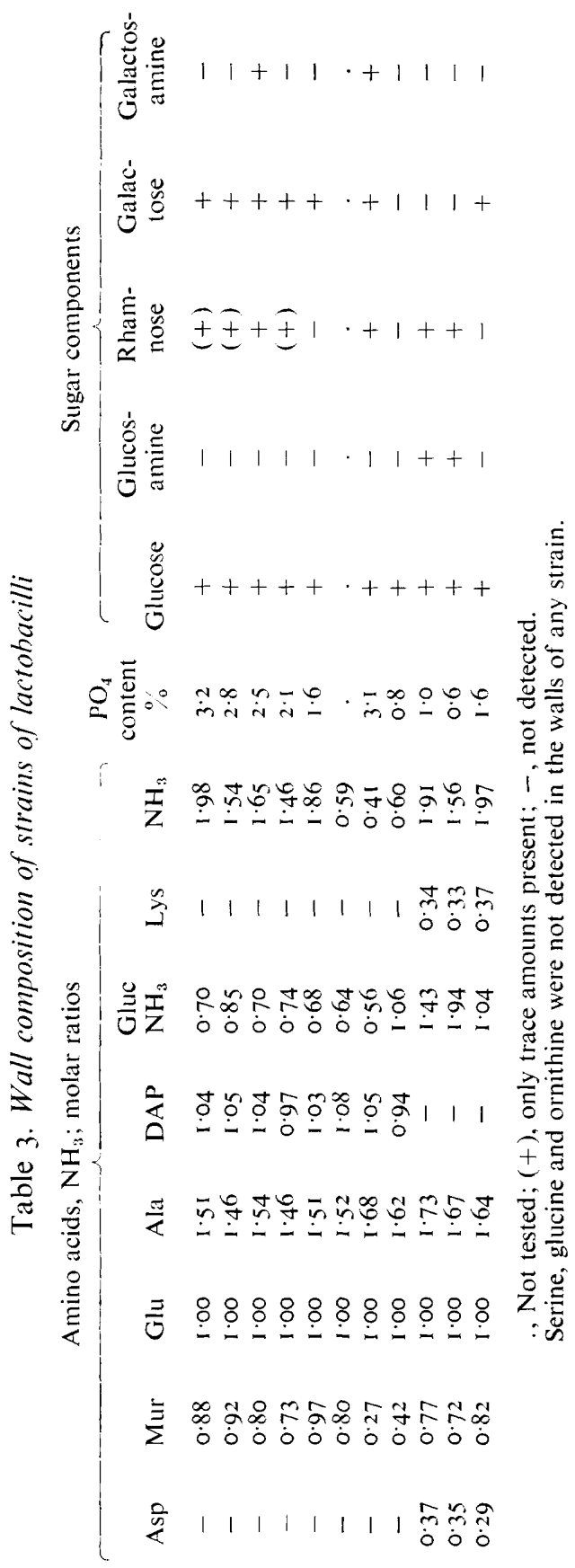

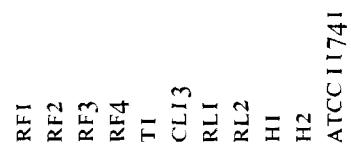




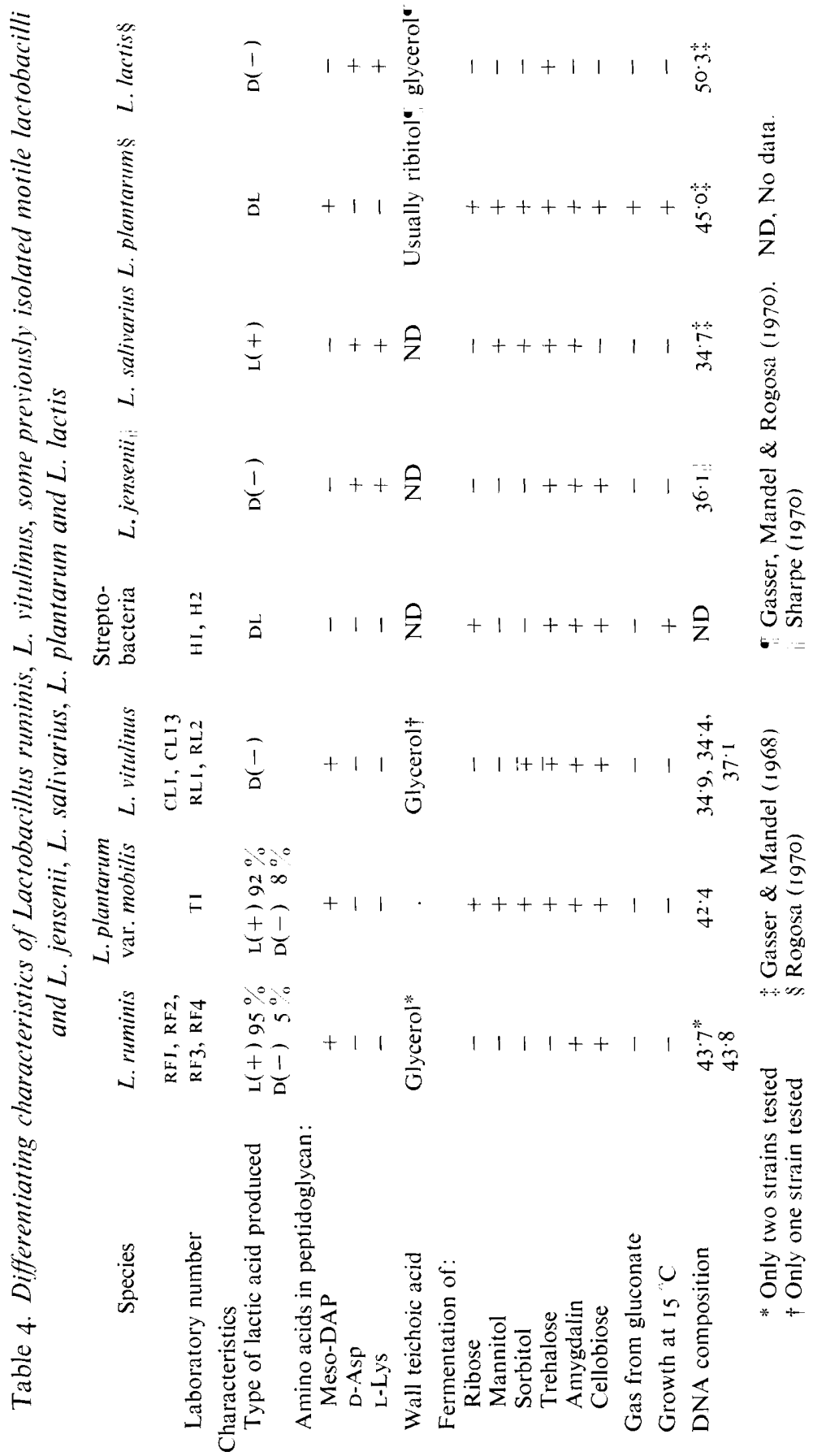


The growing culture of RFI formed very little $D(-)$-lactic acid in the medium but, when reacted with pyruvate, bacterial extracts formed a higher proportion of $\mathrm{D}(-)$-lactic acid. Using bacterial extracts at $\mathrm{pH} 8 \cdot 3,40 \%$ of the lactic acid formed was the $\mathrm{D}(-)$-isomer, but this dropped to Io to $18 \%$ at $\mathrm{pH} 7.0$ or lower.

Wall composition. The amino acid composition of the wall peptidoglycans divided the ten strains examined into three groups (Table 3). The first group included strains RFI to RF4 and TI. These all contained a meso-diaminopimelic acid (DAP)-type peptidoglycan similar to that of Lactobacillus plantarum (Weiss, Plapp \& Kandler, 1967), with no D-aspartic acid or L-lysine. The molar ratios of the amino acids, as well as the pattern of peptides in two dimensional chromatograms of partial acid hydrolysates, were almost identical in these strains. Between $\mathrm{I} \cdot 5$ and $2.0 \mathrm{~mol}$ of ammonia were found, indicating that both carboxyl groups $\alpha$-carboxyl of glutamic acid and $\omega$-carboxyl of DAP were amidated. The molar ratio of alanine was $\mathrm{I} \cdot 5$, which is also the same as that of $L$. plantarum (Weiss et al. 1967). The second group included the three non-motile strains CLI3, RLI and RL2 (CLI was not examined); these strains also contained meso-DAP type peptidoglycans and no D-aspartic acid or L-lysine. However only about $0.5 \mathrm{~mol}$ of ammonia was present, suggesting that the carboxyl groups of glutamic acid and DAP were not amidated. The third group included strains ATCCII74I, HI and $\mathrm{H} 2$ which contained L-lysine and D-aspartic acid but no mesoDAP. As shown by the molar ratios of amino acids and the pattern of peptides in the acid partial hydrolysate, the peptidoglycan present in these strains was of the L-Lys-D-Asp-type found in most other lactobacilli (Kandler, 1970).

The composition of the wall carbohydrates was more variable (Table 3). All strains in the first group except TI contained glucose, galactose and rhamnose. The two strains RLI and RL2 in the second group differed from each other in that rhamnose, galactose and galactosamine were all absent from RL2. Strains CLI and CLI3 were not examined. Strains $\mathrm{HI}$ and $\mathrm{H} 2$ were identical to each other and differed from all the other strains in containing glucosamine. They also differed from ATCC II74I.

The low phosphate content of some preparations ( $\mathrm{\%} \%$ or less) indicated that these walls contained little teichoic acid, although other strains contained significantly more phosphate in the walls. Strains RFI, RF2 and RLI, which showed the highest phosphate content, were examined in some detail. Glycerol, but no ribitol, was found in the walls of all three strains.

Deoxyribonucleic acid base composition. Strains RF1, RF2, TI, CLI3, RLI and RL2 were examined. The $\%$ GC ratios were $43 \cdot 8,43 \cdot 7,42 \cdot 4,37 \cdot 1,34 \cdot 9$ and $34 \cdot 4$ respectively (Table 4 ). The two RF strains and TI, therefore, had \% GC ratios within the range of Lactobacillus plantarum, whilst that of CL13, RLI and RL2 were within the range for L. salivarius (Gasser \& Mandel, I968).

Agglutination tests. When suspensions of the Io strains RFI to 4, TI, RLI, RL2, HI, H2 and ATCC I I 74I were tested against antiserum RFI diluted I/20, agglutination occurred only with strains RFI, RF2, RF3 and TI. The agglutination titres of these strains were 640, 320, 320 and 20 respectively. There was no agglutination reaction with strain RF4. Whilst RFI, RF2 and RF3 appeared to have a common agglutinating antigen, this was not present in strain RF4. The reaction with TI occurred at too low a titre to be significant.

\section{DISCUSSION}

The six fresh rumen isolates have the morphological characteristics of lactobacilli. They produce lactic acid but not acetic acid or $\mathrm{CO}_{2}$ from glucose. They grow well at $45^{\circ} \mathrm{C}$ but not at $15{ }^{\circ} \mathrm{C}$. They fail to ferment ribose or to produce gas from gluconate. Thus they fall 
into the subgenus Thermobacterium (Rogosa, 1970). Anaerobic lactobacilli, containing meso-DAP and belonging to the subgenus Thermobacterium, have not previously been described. However, these organisms conform to the characteristics of the genus Lactobacillus and there seems no reason at present to assign them elsewhere.

The four motile strains differ from other motile lactobacilli previously described in requiring anaerobic conditions. In addition motile strains from silage (Langston \& Bouma, I960; Gemmell \& Hodgkiss, I964), from chicken meat (Thornley \& Sharpe, 1959), and from meat products (strains $\mathrm{HI}$ and $\mathrm{H} 2$ examined here) were all low temperature strains with physiological characteristics different from those of the rumen isolates. The sporeforming lactobacillus Sporolactobacillus imulinus (Kitahara \& Suzuki, 1963) is motile and also contains the meso-DAP type peptidoglycan (Kandler, I970). However, this organism grows well aerobically, forms $\mathrm{D}(-)$-lactic acid, ferments mannitol and sorbitol but not cellobiose or salicin, and also forms spores.

The most closely related motile lactobacilli are Lactobacillus plantarum var. mobile (designated $\mathrm{T} 1$ in our work) and strain 678 of Mann \& Oxford (I954), isolated from the rumen of a 33-day-old, aureomycin-fed calf; the latter strain had the same fermentation reactions and produced the same type of lactic acid as TI, and was considered by Mann \& Oxford to be very similar to this organism. Our strains are similar to TI in having a mesoDAP type peptidoglycan, in forming the same proportion of $\mathrm{L}(+)$ - and $\mathrm{D}(-)$-lactic acids and in having a similar GC ratio (Table 4 ). However, our organisms require anaerobic conditions, and do not ferment ribose, sorbitol, mannitol or trehalose. Ribose and mannitol are regarded as useful criteria for subgeneric and species differentiation. Indeed, Rogosa ( 1970 ) suggested that one of the characteristics dividing lactobacilli into subgroups thermobacteria, streptobacteria and betabacteria is the inability of the thermobacteria to ferment ribose. The most closely related non-motile lactobacillus is $L$. plantarum which also has the meso-DAP type peptidoglycan and a similar GC ratio (Table 4). However, L. plantarum produces DL-lactic acid and is a member of the streptobacteria. We therefore consider our strains to be a new species of Thermobacterium, to be named Lactobacillus ruminis sp.nov.

The four non-motile lactobacilli CL1, CL13, RLI and RL2 appear to belong to yet another group in the subgenus Thermobacterium, also having the meso-DAP type wall peptidoglycan and not the L-Lys-D-Asp-type, but differing from Lactobacillus ruminis in lacking motility, in having no amide groups in the wall peptidoglycan (Table 3 ), forming $\mathrm{D}(-)$-lactic acid and having a different $\mathrm{GC}$ ratio $(35.7 \%)$. They appear to resemble the newly described species L. jensenii (Gasser, Mandel \& Rogosa, 1970) which also forms $D(-)$-lactic acid and has a GC ratio of $36 \cdot 1 \%$ and the same fermentation pattern (Table 4). However, L. jensenii has the D-Asp-L-Lys-type wall peptidoglycan, grows aerobically and hydrolyses arginine.

Strains RLI and RL2, strains B62 and TI 85 of Bryant et al. 1958, were regarded by these workers as belonging to two different groups on the basis of morphology and production of traces of gas, ability to grow at $22{ }^{\circ} \mathrm{C}$ and fermentation of trehalose but not inulin by the RLI group. As RLI was identical in fermentation reactions, type of lactic acid produced and growth temperatures, to an anaerobic lactobacillus from the rumen of a calf, previously isolated and tentatively identified by Mann \& Oxford (1954) as an atypical strain of Lactobacillus lactis, RLI was also considered by Bryant et al. (I 958) to be L. lactis. However our more detailed examination shows that RLI differs from L. lactis in having a meso-DAP type of wall peptidoglycan, in \% GC and in fermenting amygdalin and cellobiose (Table 4).

Although RLI and RL2 differ from each other as referred to above, and in the wall carbohydrate composition (Table 3 ), they are similar enough to assign them at the present time 
to the same species, although they are recognized as different varieties. The two fresh isolates CLI and CLI3 resemble RL2 in their club-shaped morphology, weak fermentation of inulin, and lack of fermentation of trehalose (Table 2). These four organisms differ sufficiently from other species of thermobacteria to be designated as a new species, and are assigned the name Lactobacillus vitulinus sp.nov. Strain RL2 (TI85) was one of seven similar strains examined by Bryant et al. (1958) and was the only one to ferment sorbitol. However, as it is the earliest strain extant on which further work has now been done, this should be the type strain.

Strains RLI and RL2 and Mann \& Oxford's strain I23, which probably was also a strain of Lactobacillus vitulinus, were isolated from young calves. However, CLI and CLI 3 came from a 6-month-old steer, and Bryant (personal communication) has isolated from adult cows strains similar to RL2 except that they did not ferment lactose. Such lactobacilli are therefore likely to be present in adult animals and may be isolated when the animal is on a suitable diet.

These DAP-containing lactobacilli, if present in large numbers in the rumen, may affect estimations of microbial nitrogen. The amount of DAP present in the digesta of sheep has been used to determine bacterial $\mathrm{N}$ in the presence of other $\mathrm{N}$ passing from the rumen, through the intestine, to the faeces (Mason, 1969; Smith, 1969; Mason \& White, 1970). On high-roughage, or mixed, rations the largely Gram-negative bacterial species in the rumen will generally contain DAP in the wall (Work, 1970), and this measurement may be relevant. However, on a high-carbohydrate ration the DAP content may not reflect the bacterial population: streptococci, lactobacilli and bifidobacteria may constitute a high proportion of the bacterial flora (Latham et al. I97I) and none of these bacteria except Lactobacillus plantarum contain DAP (Synge, I953; Gooder, 1970; Kandler, I970). Large numbers of the DAP-containing lactobacilli in the rumen of a cow on a high-carbohydrate ration would result in a higher estimation of microbial nitrogen than that found when other lactic acid bacteria were present, unless estimations were made of the DAP content of the rumen flora in the experimental animal at the time of estimation of intestinal microbial nitrogen.

Motile lactobacilli may be common inhabitants of the digestive tract, as Sharpe et al. (1969) demonstrated the presence of agglutinating antibodies to RFI not only in the serum of the cow from which it was isolated but also in that of other ruminants and a horse.

The lactate dehydrogenases of Lactobacillaceae are useful species characteristics for differentiation (Garvie, I969; Gasser, 1970). The L(+)-lactate dehydrogenase in strain RFI appears to be similar to the enzyme in Lactobacillus jugurt (Gasser, Doudoroff \& Contopoulos, 1970), in that it has a low optimum $\mathrm{pH}$ and is only weakly reversible. The $D(-)$-enzyme has similar characteristics to the $D(-)$-enzymes of most other lactobacilli and it is not clear why the $\mathrm{L}(+)$-enzyme is dominant in the growing culture and in crude enzyme preparations. As $L$. casei also forms predominantly $L(+)$-lactic acid it seemed possible that the lactate dehydrogenases of RFI might be similar. However, this was not so, as the $\mathrm{L}(+)$-lactate dehydrogenase of $L$. casei requires fructose-I,6-diphosphate and the $\mathrm{D}(-)$-enzyme is active with pyruvate, but not lactate, as substrate (E. I. Garvie, unpublished). 


\section{Description}

Lactobacillus ruminis sp.nol.

Homofermentative, producing mostly $\mathrm{L}(+)$ - and about $5 \% \mathrm{D}(-)$-lactic acid.

DNA base composition: $43 \cdot 7 \pm 0 \cdot \mathrm{I} \mathrm{mol} \% \mathrm{G}+\mathrm{C}$.

Growth at $45^{\circ} \mathrm{C}$ but not at $15^{\circ} \mathrm{C}$.

Motile, with peritrichous flagella.

Amino acid type in wall peptidoglycan: meso-DAP.

Fructose, glucose, mannose, galactose, sucrose, maltose, cellobiose, melibiose, raffinose, salicin, amygdalin and aesculin fermented; xylose, arabinose, ribose, rhamnose, melezitose, inulin, trehalose, mannitol, sorbitol, glycerol, inositol not fermented; lactose fermented by some strains.

Arginine not hydrolysed.

The type strain RFI has been deposited in the National Collection of Dairy Organisms.

Lactobacillus vitulinus sp.nov.

\section{Description}

Homofermentative, producing $\mathrm{D}(-)$-lactic acid.

DNA base composition: $35 \cdot 7 \pm \mathbf{1} \cdot 3 \mathrm{~mol} \% \mathrm{G}+\mathrm{C}$.

Growth at $45^{\circ} \mathrm{C}$ but not at $15{ }^{\circ} \mathrm{C}$.

Non-motile.

Amino acid type in wall peptidoglycan: meso-DAP.

Fructose, glucose, mannose, galactose, sucrose, maltose, cellobiose, melibiose, lactose, raffinose, salicin, amygdalin and aesculin fermented; xylose, arabinose, ribose, rhamnose, melezitose, mannitol, glycerol, inositol not fermented; inulin, trehalose, sorbitol may be fermented.

Arginine not hydrolysed.

The type strain TI 85 has been deposited in the National Collection of Dairy Organisms.

The authors wish to thank Mr L. R. Hill for some of the determinations of the DNA base compositions; Dr D. G. Smith for electron microscopy; and Mr B. A. Phillips for expert technical assistance.

\section{REFERENCES}

Abo Elnaga, J. \& Kandler, O. (I965). Zur Taxonomie der Gattung Lactobacillus Beijerinck. I. Das Subgenus Streptobacterium Orla Jensen. Zentralhlatt fïr Bakteriologie, Parasitenkunde Infektionskrank heiten und Hygiene (Abteiling II) Ix9, I-36.

Bergmeyer, M. U. (I962). Methoden der enzymatischen. Analyse. Weinheim Verlag Chemie.

Bryant, M. P. \& Small, S. N. (1956). The anaerobic monotrichous butyric acid-producing curved rodshaped bacteria of the rumen. Journal of Bacteriology 72, 16-26.

Bryant, M. P., Small, S. N., Bouma, C. \& Robinson, I. (1958). Studies on the composition of the ruminal flora and fauna of young calves. Journal of Dairy Science 4r, 1747-1767.

Caldwell, D. R. \& BRyAnt, M. P. (1966). Medium without rumen fluid for non-selective enumeration and isolation of rumen bacteria. Applied Microbiology 14, 794-80.

Fiske, C. M. \& Subbarow, Y. (1925). The colorimetric determination of phosphorus. Journal of Biological Chemistry 66, 375-377.

Garvie, E. I. (1967). The production of L ( +) and D (-) lactic acid in culture of some lactic acid bacteria with a special study of Lactobacillus acidophilus NCDO 2. Journal of Dairy Research 34, 3I-38.

GARviE, E. I. (1969). Lactic dehydrogenases of strains of the genus Leuconostoc. Journal of General Microbiology 58, 85-94. 
GASSER, F. (1970). Electrophoretic characterization of lactic dehydrogenases in the genus Lactobacillus. Journal of General Microbiology 62, 223-239.

Gasser, F., Doudoroff, M. \& Contopoulos, R. (1970). Purification and properties of NAD-dependent lactic dehydrogenases of different species of Lactobacillus. Journal of General Microbiology 62, 241-250.

GASSER, F. \& MANDEL, M. (1968). Deoxyribonucleic acid base composition of the genus Lactobacillus. Journal of Bacteriology $96,580-588$.

Gasser, F., MANDEL, M. \& Rogosa, M. (1970). Lactobacillus jensenii sp.nov., a new representative of the subgenus Thermobacterium. Journal of General Microbiology 62, 219-222.

Gemmell, M. \& Hodgkiss, W. (1964). The physiological characters and flagellar arrangement of motile homofermentative lactobacilli. Journal of General Microbiology 35, 519-526.

GoODER, H. (1970). Cell wall composition in the classification of streptococci. International Journal of Systematic Bacteriology 20, 475-482.

Harper, W. J., Schwartz, D. P. \& El-Hagarawy, I. S. (I956). A rapid silica gel method for measuring total free fatty acids in milk. Journal of Dairy Science 39, 46-50.

Harrison, A. P., Jun. \& Hansen, A. P. (1950). A motile lactobacillus from the cecal feces of turkeys. Journal of Bacteriology 59, 444-446.

Hungate, R. E. (1950). The anaerobic mesophilic cellulolytic bacteria. Bacteriological Reviews I4, I-49.

KANDLER, O. (1970). Amino acid sequence of the murein and taxonomy of the genera Lactobacillas, Bifidobacterium, Leuconostoc and Pediococcus. International Journal of Systematic Bacteriology 20, 49 I-508.

Kitahara, K. \& Suzuki, J. (1963). Sporolactobacillus nov. subgen. Journal of General and Applied Microbiology 9, 59-7I.

Langston, C. W. \& Bouma, C. (I960). A study of the microorganisms from grass silage. II. The lactobacilli. Applied Microbiology 8, 223-234.

Latham, M. J. \& Sharpe, M. E. (I97I). The isolation of anaerobic organisms from the bovine rumen. In Isolation of Anaerobes, p. 133. Edited by D. A. Shapton \& R. G. Board. London: Academic Press.

Latham, M. J., Sharpe, M. E. \& Sutton, J. D. (197I). The microbial flora of the rumen of cows fed hay and high cereal rations and its relationship to rumen fermentation. Journal of Applied Bacteriology 34, $425-435$.

de Man, J. C., Rogosa, M. \& Sharpe, M. E. (1960). A medium for the cultivation of lactobacilli. Journal of Applied Bacteriology 23, I 30-1 35.

MANN, S. O. \& OxFord, A. E. (1954). Studies of some presumptive lactobacilli isolated from the rumens of young calves. Journal of General Microbiology Ir, 83-90.

Marmur, J. \& Doty, P. (1962). Determination of the base composition of deoxyribonucleic acid from its thermal denaturation temperature. Journal of Molecular Biology 5, 109-118.

Mason, V. C. (1969). Some observations on the distribution and origin of nitrogen in sheep faeces. Journal of Agricultural Science 73, 99-112.

Mason, V.C. \& White, F. (I970). Some observations on the metabolism of $-\mathrm{E}$ diaminopimelic acid in sheep. Proceedings of the Nutrition Society $30,13 \mathrm{~A}$.

REUTER, G. (1970). Laktobazillen und eng verwandte Mikroorganismen in Fleisch und Fleischerzeugnissen. Fleischwirtschaft $\mathbf{5 0}, 954-962$.

Rhodes, M. (1958). The cytology of Pseudomonas spp. as revealed by a silver plated staining method. Journal of General Microbiology 18, 639-648.

Rogosa, M. (1970). Characters used in the classification of lactobacilli. International Journal of Systematic Bacteriology 20, 519-534.

Rogosa, M., Mitchell, J. A. \& Wiseman, R. F. ( I95I). A selective medium for the isolation and enumeration of oral and fecal lactobacilli. Journal of Bacteriology 62, 132.

Schleifer, K. H. \& KandLer, O. (1967). Die Aminosäuresequenz des Mureins von Streptococcus thermophilus und Str. faecalis. Archiv fïr Microbiologie 57, 335-364.

SCHLEIFER, K. H. \& KANDleR, O. (1970). Amino acid sequence of the murein of Planococcus and other Micrococcaceae. Journal of Bacteriology ro3, 387-392.

Sharpe, M.E. (I970). Cell wall and cell membrane antigens used in the classification of lactobacilli International Journal of Systematic Bacteriology 20, 509-518.

Sharpe, M. E., Fryer, T. F. \& SMith, D. G. ( 1966). In Identification Methods for Microbiologists. Edited by B. M. Gibbs and F. A. Skinner. London and New York: Academic Press.

Sharpe, M. E., LAtham, M. J. \& Reiter, B. ( 1969 ). The occurrence of natural antibodies to rumen bacteria. Journal of General Microbiology 56, 353-364.

SмIтH, R. H. (1969). Reviews of the progress of Dairy Science Section G. General. Nitrogen metabolism and the rumen. Journal of Dairy Research 36, 313-331. 
SYNGE, R. L. M. (1953). Note on the occurrence of diaminopimelic acid in some intestinal micro-organisms from farm animals. Journal of General Microbiology 9, 407-409.

Thornley, M. J. \& Sharpe, M. E. (1959). Microorganisms from chicken meat related to both lactobacilli and aerobic sporeformers. Journal of Applied Bacteriology 22, 368-376.

Trevelyan, W. E., Procter, D. D. \& Harrison, J. S. (1950). Detection of sugars on paper chromatograms. Nature, London 166, 444-448.

Weiss, N., Plapp, R. \& Kandler, O. (1967). Die Amino-Säuresequenz des DAP-haltigen Mureins von Lactobacillus plantarum und Lactobacillus inulinus. Archiv für Mikrobiologie 58, 3I 3-323.

WORK, E. (1970). The distribution of diamino acids in cell walls and its significance in bacterial taxonomy. International Journal of Systematic Bacteriology 20, 425-434. 